\title{
Promising Selections of the Honeyberry (Melicocca bijuga L.) from Puerto Rico ${ }^{1}$
}

\author{
George C. Jackson ${ }^{2}$
}

\section{INTRODUCTION}

The tropical tree, Melicocca bijuga L., is indigenous to the Western Hemisphere $(6,7){ }^{3}$ The edible fruit produced by this plant is known by many common names: Anoncillo, Genip, Honeyberry, Jamaica Bullace Plum, Kanappy, Knippa, Knippleboom, Maco, Mamoncillo, Quenepa, Spanish Lime, Tackeboom, and others. The value of the plant as a fruit tree has been discussed $(5,8,10,11,16)$.

The nutritional aspects of the fruit have been investigated and values for riboflavin, thiamine, niacin $(1,2,3,13,14)$, ascorbic acid $(9,12,13,14)$, calcium, phosphorus, and iron $(13,14)$, have been published.

Literature search indicates that very little selection work has been accomplished. Ledin (10) reports on the selection of a sweet type from Key West, Fla.

The purpose of the present study was the selection of a honeyberry ( $M$. bijuga L.) fruit high in sugars and yielding a large amount of edible pulp.

\section{PROCEDURE}

More than 54 trees in south Puerto Rico were selected on the basis of previous reports as yielding fruit of excellent quality. These trees were visited during season and the fruits subjected to repeated organoleptic examinations in the field. The fruit samples were free of all physiological and pathological disorders and were taken from apparently healthy trees. The following fruit characters were considered undesirable: High acidity, bland or disagreeable flavors, pulp difficult to remove from seed, undesirable pulp color, excessive juiciness, small amount of edible pulp, thin peel, and high incidence of split peels. Nine trees produced fruit considered worthy of

1 This study was conducted under Commonwealth Grant as Project C-330.

2 Formerly Assistant Horticulturist, Fortuna Substation, Agricultural Experiment Station, University of Puerto Rico, Río Piedras, P.R. Present address, Productos Libby's International Ine., Box 584, Santa Isabel, P.R. 00757. The author wishes to express his thanks to the staff of the Central Analytical Laboratory, Agricultural Experiment Station, Río Piedras, P.R. He is also grateful for the enthusiastic cooperation of the Agricultural Extension Service, Río Piedras, and especially the Extension Service personnel in the cities of Cabo Rojo, Coamo, Guayanilla, Guayama, Juana Díaz, Lajas, Peñuelas, Ponce, Salinas, and Yauco, P. R.

${ }^{3}$ Italic numbers in parentheses refer to Literature Cited, pp. 69-70. 
further testing. Samples of fruit were collected from these trees and taken to the laboratory for physical and chemical evaluation.

Two hundred random selected fruits of each sample were divided into 20 lots of 10 fruits each and placed in numbered plastic bags.

The 10 fruits of each lot were weighed on a laboratory gram scale, and the weights recorded (table 1 ).

The fruit was then carefully peeled and the fresh peel weight recorded (table 1).

All edible pulp was carefully removed and the seeds washed in clean tapwater and then dried with a clean cloth. Fresh seed weight was recorded (table 1).

TABLE 1.-Average weights of selections of fruit, their peel, seed, and edible pulp of the honeyberry, Melicocca bijuga $\mathbf{L}$.

\begin{tabular}{|c|c|c|c|c|c|}
\hline \multirow{2}{*}{ Sample } & \multicolumn{4}{|c|}{ Weight of- } & \multirow{2}{*}{ Pulp } \\
\hline & Fruit & Peel & Seed & Pulp & \\
\hline & G. & G. & G. & G. & Percent \\
\hline A & 16.08 & 3.09 & 5.27 & 7.72 & 48.01 \\
\hline B & 10.68 & 3.03 & 3.03 & 4.62 & 43.26 \\
\hline $\mathrm{C}$ & 16.02 & 2.94 & 5.23 & 7.85 & 49.00 \\
\hline $\mathrm{D}$ & 16.57 & 4.03 & 4.82 & 7.72 & 46.59 \\
\hline $\mathrm{E}$ & 21.92 & 6.19 & 5.58 & 10.15 & 46.30 \\
\hline $\mathrm{F}$ & 13.51 & 3.76 & 4.29 & 5.46 & 40.41 \\
\hline G & 9.35 & 2.25 & 2.56 & 4.54 & 48.56 \\
\hline $\mathrm{H}$ & 12.12 & 2.37 & 2.55 & 7.20 & 59.42 \\
\hline$J$ & 11.18 & 2.90 & 2.90 & 5.38 & 48.12 \\
\hline
\end{tabular}

The total edible pulp and the difference between whole-fruit weight and peel and seed weight were determined and recorded (table 1).

The percentage of edible pulp was then determined and recorded (table $1)$.

The $\mathrm{pH}$ of fresh fruit juice was determined on a laboratory $\mathrm{pH}$-meter (table 2).

The total soluble solids of the fresh juice was determined on a laboratory refractometer (table 2).

The citric acid content of fresh juice was determined by titration with $0.1 \mathrm{~N}$ alkali solution using a glass electrode (15), (table 2).

Total sugars were determined as invert (table 2), (15).

The percentage moisture of fresh pulp was determined by drying the pulp to constant weight at $100^{\circ} \mathrm{C}$. (15). The moisture was then calculated, and varied from 77.2 to 83.4 , with an average of 80.7 percent.

As a check on previously reported ascorbic acid values, the iodometric 
method of Ballentine (4) was employed. The vitamin C content of fresh juice ranged from 7 to $17 \mathrm{mg}$. per $100 \mathrm{~g}$. of edible matter, with an average of $12.2 \mathrm{mg}$. ascorbic acid per $100 \mathrm{~g}$. edible matter.

\section{DISCUSSION AND EVALUATION}

The average vitamin $\mathrm{C}$ content of $12.2 \mathrm{mg}$. per $100 \mathrm{~g}$. of edible matter was higher than values previously published for Nicaragua (14), Puerto Rico (12), El Salvador (13), and Venezuela (9), which was 3.1, 6.7, 10.0, and $11.3 \mathrm{mg}$. per $100 \mathrm{~g}$. of edible matter, respectively.

TABLe 2.-Percent edible pulp, PH, total soluble solids, citric acid, and percent total sugars of the honeyberry, M. bijuga $\mathbf{L}$.

\begin{tabular}{|c|c|c|c|c|c|}
\hline Sample & Pulp & $\mathrm{pH}$ & $\begin{array}{l}\text { Total soluble } \\
\text { solids }\end{array}$ & $\begin{array}{l}\text { Citric acid per } \\
10 \mathrm{ml} \text {. of juice }\end{array}$ & Total sugars \\
\hline & Percent & & & $M g$. & Percent \\
\hline A & 48.01 & 3.31 & 18.8 & 1,561 & 26.01 \\
\hline B & 43.26 & 3.27 & 23.7 & 1,468 & 19.03 \\
\hline $\mathrm{C}$ & 49.00 & 3.96 & 18.5 & 764 & 18.20 \\
\hline D & 46.59 & 3.73 & 24.9 & 694 & 24.09 \\
\hline $\mathrm{E}$ & 46.30 & 3.42 & 22.6 & 1,291 & 19.91 \\
\hline $\mathrm{F}$ & 40.41 & 3.66 & 22.0 & 1,207 & 19.50 \\
\hline $\mathrm{G}$ & 48.56 & 4.00 & 25.6 & 498 & 24.09 \\
\hline $\mathrm{H}$ & 59.42 & 4.00 & 19.9 & 333 & 14.63 \\
\hline$J$ & 48.12 & 3.42 & 24.4 & 1,369 & 22.76 \\
\hline
\end{tabular}

Only fruits having 45-percent edible matter or more, and total sugars of 20 percent or more were considered for selection. A description of the selections is as follows:

\section{PUERTO RICO 1}

(Sample A), Fruit medium size, 28 fruit to the pound. Peel smooth, light-green in color, fruit globose, flesh firm, semidry, easily removed from the seed, and light-honey in color. Fruit flavorsome, pleasantly sweet 26.0 percent of sugar, with 48.0 percent of total weight edible.

\section{PUERTO RICO 2}

(Sample D), Fruit medium size, 27 fruit to the pound. Peel smooth, medium thick, light-green in color. Fruit globose, flesh firm, semidry, easily removed from the seed, and light-honey in color. Flavor pleasant, sweet, 24.1 percent of total sugars, with 46.6 percent of the total weight edible.

\section{PUERTO RICO 3}

(Sample G), Fruit small, 49 to the pound, peel smooth, green-yellow, thin, but not brittle. Fruit oblong-globose, flesh firm, semidry, easily re- 
moved from the seed. Flavor agreeable, very sweet, 24.1 percent total sugar, 48.6 percent of total weight edible, flesh-honey color.

\section{PUERTO RICO 4}

(Sample J), Fruit medium-small, 40 fruit to the pound. Peel slightly rugose, color dark green, peel medium thin. Fruit globose, flesh firm, semidry, easily removed from the seed, dark-honey color. Flavor pleasantly acid, slightly sweet, 22.7 percent of total sugar, 48.0 percent of total weight edible.

\section{SUMMARY}

The tropical tree, Melicocca bijuga L., native of the Western Hemisphere, produces an edible fruit which is very much appreciated when those of quality can be obtained. Nutritional value and previous selection work is reviewed. Four promising selections were made from 54 trees evaluated in south Puerto Rico. The methods employed involved measurements of fruit weight, percentage edible pulp, $\mathrm{pH}$, total soluble solids, citric acid content, percentage total sugars, and vitamin $\mathrm{C}$ content.

The four selections made had 46.6 to 48.6 percent of edible matter by weight, and contained 22.7 to 26.0 percent of total sugars. Descriptions of the four selections are presented.

\section{RESUMEN}

EI árbol tropical, Melicocca bijuga L., indígena del hemisferio occidental, produce una fruta comestible, la cual es muy apreciada cuando es de primera calidad. Se ha estudiado en este trabajo tanto el valor nutritivo de la fruta como el trabajo de selección llevado a cabo anteriormente por otros investigadores. De 54 árboles estudiados en el sur de Puerto Rico, 4 se destacan como selecciones prometedoras. Los métodos empleados tomaron en cuenta el peso de la fruta, porcentaje de pulpa comestible, $\mathrm{pH}$, total de sólidos solubles, contenido de ácido cítrico, porcentaje total de azúcares y vitamina C. Estas cuatro selecciones contienen de 46.6 a 48.6 por ciento de materia comestible por peso, además de un 22.7 a 26.0 de azúcares totales. Se incluye la descripción de estas cuatro selecciones.

\section{LITERATURE CITED}

1. Asenjo, C. F., García de la Noceda, H., and Serrano, P., Riboflavin content of tropical foods, Food Res. 11(2): 137-41, 1946.

2. Asenjo, C. F., Segundo, O. de B., and Garci de la Noceda, H., Thiamine content of tropical foods, Food Res. 13(1): 94-9, 1948.

3. Asenjo, C. F., Segundo, O., de B., Muñiz, A. I., and Canals, A. M., Niacin content of tropical foods, Food Res. 15(6): 465-70, 1950.

4. Ballentine, R., Determination of ascorbic acid in citrus fruit juices, Ind. Eng. Chem., Anal. Ed. 1s(2): 89, 1941. 
5. Barrett, O. W., The food plants of Porto Rico, J. Dept. Agr. P.R. 9(2): pp. 175, 1925.

6. Britton, N. L., and Wilson, P., Scientific survey of Porto Rico and the Virgin Islands, N.Y. Acad. Sci. 5(1): pp. 529, 1923.

7. Faweett, W., and Rendle, A. B., Flora of Jamaica, Brit. Mus. Nat. Hist. 5 (3) : pp. $53,1926$.

8. Kennard, W. C., and Winters, H. F., Some fruits and nuts for the tropics, U. S. Dept. Agr. Misc. Pub. 801, pp. 86, 1960.

9. Jaffe, W. G., Budowski, P., and Gorra, C., Estudio sobre el contenido de ácido ascórbico (vitamina C) en las principales frutas de Venezuela, Arch. Ven. Nutr. $1(1): 83-106,1950$.

10. Ledin, R. B., Tropical and subtropical fruits in Florida (other than citrus), Econ. Bot. $11(4)$ : pp. 366, 1957.

11. Mowery, H., and Toy, L. R., Miscellaneous Tropical and Subtropical Florida Fruits, Univ. Fla. Agr. Ext. Serv. Bull. 233, pp. 80, 1931: Revised by H. F. Wolf, Bull. 85, 1936; revised by H. F. Wolf, Bull. 109, 1941; revised by G. D. Ruehle, Bull. 156, 1953; revised by G. D. Ruehle, Bull. 156A, 1958.

12. Munsell, H. E., Ascorbic acid content of fruits of Puerto Rico with data on miscellaneous products, Food. Res. 10: 42-51, 1945.

13. Munsell, H. E., Williams, L. O., Guild, L. P., Troescher, C. B., Nightengale, G., Kelly, L. T., and Harris R. S., Composition of food plants of Central America IV, El Salvador, Food. Res. 15: 263-96, 1950.

14. Munsell, H. E., Williams, L. O., Guild, L. P., Troescher, C. B., and Harris, R. B., Composition of food plants of Central America V, Nicaragua, Food Res., 15: $335-65,1950$.

15. Official Methods of Analysis of the Association of Official Agricultural Chemists, 9th ed., Washington, D.C., 1960.

16. Salazar, C. G., Algunas frutas tropicales de menor importancia económica en Puerto Rico, Rev. Agr. P. R. $42(2)$ : pp. 143, 1959. 